\title{
Occupation as a Proxy for Job Exposures? Routine Data Analysis Using the Example of Rehabilitation
}

\author{
Berufståtigkeit als Proxy für Arbeitsbelastungen? \\ Routinedatenanalyse am Beispiel der Rehabilitation
}

\section{(ㄷ) (i) $(-)$}

\author{
Authors \\ Martin Brünger ${ }^{\mathbb{D}}$, Sebastian Bernert, Karla Spyra
}

\begin{abstract}
Affiliation
Institute of Medical Sociology and Rehabilitation Science, Charité - Universitätsmedizin Berlin, corporate member of Freie Universität Berlin, Humboldt-Universität zu Berlin, and Berlin Institute of Health, Charitéplatz 1, 10117 Berlin, Germany
\end{abstract}

Key words

job demands, job exposures, medical rehabilitation, routine data, pension insurance, secondary data analysis

\section{Schlüsselwörter}

Arbeitsbelastung, Berufstätigkeit, Sekundärdaten, Routinedaten, medizinische Rehabilitation, Rentenversicherung

\section{Bibliography}

DOI https://doi.org/10.1055/a-0965-6777

Online-Publikation: 28.10.2019

Gesundheitswesen 2020; 82 (Suppl. 1): S41-S51

(c) Georg Thieme Verlag KG Stuttgart · New York

ISSN 0949-7013

\section{Correspondence}

Martin Brünger

Institute of Medical Sociology and Rehabilitation Science

Charité - Universitätsmedizin Berlin

Charitéplatz 1

10117 Berlin

Germany

martin.bruenger@charite.de

\section{ABSTRACT}

Aim of the study Job exposures are associated with healthrelated outcomes including sick leave and reduction in earning capacity. Rehabilitation of persons in working age aims primarily to secure or restore work capacity. Information concerning job exposures is, however, not directly available in routine data of healthcare payers. Since exposures relate to specific occupations and the current occupation is part of routine data, job exposures may be determined indirectly via job-exposure ma- trices (JEM). The aim of the study is to describe the possibilities and challenges of the representation of job exposures by the occupation according to routine data using the example of rehabilitation.

Methods The Scientific Use File 'SUFRSDLV15B' of the German Pension Insurance was analysed. We used data from n $=1242171$ persons in work with at least one completed medical rehabilitation between 2008 and 2015 (dataset 1). The occupation is coded according to KldB 88 or KldB 2010 (German Classification of Occupations). In addition, data from a nationwide survey with 2530 rehabilitation patients was available (dataset 2). Job exposures are operationalized by the Job Exposure Index via JEM. The relationship to the return-to-work prognosis at the end of rehabilitation (dataset 1 ) and to patient reported outcome measures (dataset 2 ) is described.

Results Information concerning the occupation is available for about $91 \%$ of rehabilitation measures of employed patients for the year prior to rehabilitation. At high levels of job exposures, the proportion of persons with a predicted working capacity in the last job of fewer than $3 \mathrm{~h}$ per day increased by a factor of 4 compared to low-level job exposures (23.5 vs. $6.1 \%$ ). On the other hand, there is a low association only to reduced working capacity in the general labour market (2.9 vs. $2.4 \%$ ). High-level job exposures are associated with self-reported, work-related impairments.

Conclusion The Job Exposure Index may offer a valid approach to depict occupation-related exposures. The index can be used in the analysis of routine data of the pension insurance and other social security funds, as well as in the linkage of individual assessment data with routine data containing the occupation, without any additional data collection effort. Due to its construction based on job classifications, it will not replace the assessment of individual burdens.

\section{ZUSAMMENFASSUNG}

Ziel der Studie Arbeitsbelastungen sind mit verschiedenen Gesundheitsindikatoren wie Arbeitsunfähigkeit und Erwerbsminderung assoziiert. Primäres Ziel der Rehabilitation von Personen im erwerbsfähigen Alter ist meist die Sicherung bzw. Wiederherstellung der Erwerbsfähigkeit. Allerdings sind 
Arbeitsbelastungen in Routinedaten der Kostenträger nicht verfügbar. Da viele Belastungen typisch für einzelne Berufe sind und die Tätigkeit in Routinedaten dokumentiert ist, können Arbeitsbelastungen indirekt über die Berufstätigkeit dargestellt werden. Ziel der Arbeit ist es, Möglichkeiten und Grenzen der Abbildung von Arbeitsbelastungen durch die Tätigkeit gemäß Routinedaten am Beispiel der Rehabilitation zu beschreiben.

Methodik Das Scientific Use File „SUFRSDLV15B“ der Deutschen Rentenversicherung mit 1242171 Erwerbstätigen mit mindestens einer abgeschlossenen medizinischen Rehabilitation 2008-2015 wurde analysiert (Datensatz 1). Die Tätigkeit ist nach KIdB 88 bzw. KldB 2010 (Klassifikation der Berufe) codiert. Zudem stehen Daten einer bundesweiten Befragung mit 2530 Rehabilitanden zur Verfügung (Datensatz 2). Arbeitsbelastungen wurden mithilfe eines Index über die Berufstätigkeit durch Bildung von Job-Exposure-Matrizen operationalisiert. Der Zusammenhang zur Return-to-Work-Prognose am Ende der Rehabilitation (Datensatz 1) und zu selbstberichteten Beeinträchtigungen und Ressourcen (Datensatz 2) wird berichtet.
Ergebnisse Für etwa 91 \% der medizinischen Rehabilitationen bei Erwerbstätigen liegen für das Jahr vor Rehabilitation Informationen zur Berufstätigkeit und damit zum Arbeitsbelastungsindex vor. Bei hohen Arbeitsbelastungen war der Anteil mit einer prognostizierten Arbeitsfähigkeit im letzten Beruf von weniger als 3 Stunden täglich etwa um den Faktor 4 im Vergleich zu niedriger Arbeitsbelastung erhöht (23,5 vs. 6,1\%). Hingegen besteht nur ein geringer Zusammenhang zur verminderten Leistungsfähigkeit auf dem allgemeinen Arbeitsmarkt (2,9 vs. 2,4\%). Hohe Arbeitsbelastungen sind mit selbstberichteten, insbesondere berufsbezogenen Beeinträchtigungen assoziiert.

Schlussfolgerung Der Arbeitsbelastungsindex bietet die Möglichkeit, berufstypische Arbeitsbelastungen valide abzubilden. Der Index kann bei Analysen von Routinedaten der Sozialversicherungsträger sowie bei Verknüpfung von Primärdaten mit Routinedaten, welche die Berufstätigkeit enthalten, ohne zusätzlichen Erhebungsaufwand eingesetzt werden. Aufgrund seiner Konstruktion über die Berufstätigkeit kann der Index die Erhebung von individuellen Belastungen nicht ersetzen.

\section{Introduction}

Job exposures are associated with various health-related outcomes such as injuries, morbidity, mortality, sick leave and reduction in earning capacity [1-7]. They can be differentiated into physical job exposures like harmful working environments (noise, dirt, heat, cold, toxic or allergic substances, carrying heavy weights, e.g.) and psychosocial job exposures like time pressure, low job autonomy, shift work or frequent overtime [8-10].

As the main aim in the rehabilitation of patients in working age is usually return-to-work, working conditions can play an important role in achieving that aim. Therefore, job exposures should be considered in studies dealing with return-to-work after rehabilitation. However, individual job exposures are frequently not assessed in clinical or epidemiological studies. Common instruments to assess job exposures are extensive and often focus on certain aspects of job exposures only, e. g. the Copenhagen Psychosocial Questionnaire (COPSOQ) [11]. In routine data - for example of the Statutory Health Insurance or the German Pension Insurance -, there is no explicit information available concerning job exposures. Hence, it is not possible to take into account job exposures in routine data analyses directly.

It is known that many job exposures relate to specific occupations. This offers the possibility to represent job exposures via socalled job-exposure matrices: Job exposures measured individually in previous studies are assigned to the person's occupation. This information can then be used in any other epidemiological study or routine data analysis if the current occupation is available in the dataset. The use of job-exposure matrices is well established in occupational epidemiological research [12-18].

There are different classifications of occupations applied both for administrative purposes and for scientific studies. By law, all employers in Germany are obliged to transmit yearly information con- cerning the occupation and education (amongst other information) for all employees to the Statutory Health Insurance. From there, this data is transferred to the German Pension Insurance and further on to the Federal Employment Agency ("Datenerfassungs- und Übermittlungsverordnung” (DEÜV)) [19]. The occupation has to be coded according to the German Classification of Occupations 2010 (KIdB 2010) [20] since 1.12.2011 [21]. Before, occupations were documented according to the first 3 digits of the Classification of Occupations 1988 (KIdB 88). The Federal Statistical Office used the similar Classification of Occupations 1992 (KldB 92), e.g. for the microcensus.

For international comparisons, the International Standard Classification of Occupations (ISCO) by the International Labour Organization is widely used [22]. 2008 the fourth version ISCO-08 succeeded the previous version ISCO-88 [23]. KIdB 2010 and ISCO-08 are more comparable than their predecessors were. The classifications mentioned are also used for job coding in various surveys and other large epidemiological studies or survey data which is linked to routine data that contains the occupation code [24-27].

All job classifications mentioned have in common that they consist of a hierarchical structure. In KIdB 2010 for example, there are 1286 occupational types nested within 700 sub-groups, 144 groups, 37 main groups and 10 occupational areas [20]. This allows to both assess and to take into consideration job exposures via jobexposure matrices on different hierarchical levels of occupations. - Table 1 provides an overview of the structure and usage of the most important occupation classifications in Germany and on an international level. With some limitations regarding the precision, the job classifications mentioned can be transformed into each other.

The aim of this work is to illustrate the possibilities and limitations of using the occupation documented in routine data and its 
- Table 1 Classifications of occupations: Structure and usage.

\begin{tabular}{|c|c|c|c|c|c|}
\hline & KIdB 88 & KIdB 92 & KIdB 2010 & ISCO-88 & ISCO-08 \\
\hline \multicolumn{6}{|c|}{ Occupation level (n) } \\
\hline 1 & $\begin{array}{l}\text { occupational area } \\
(n=6)\end{array}$ & $\begin{array}{l}\text { occupational } \\
\text { area }(n=6)\end{array}$ & $\begin{array}{l}\text { occupational areas } \\
(\mathrm{n}=10)\end{array}$ & $\begin{array}{l}\text { major group } \\
(n=10)\end{array}$ & $\begin{array}{l}\text { major group } \\
(n=10)\end{array}$ \\
\hline \multirow[t]{2}{*}{2} & $\begin{array}{l}\text { occupational } \\
\text { section }(n=33)\end{array}$ & $\begin{array}{l}\text { occupational } \\
\text { section }(n=33)\end{array}$ & \multirow[t]{2}{*}{$\begin{array}{l}\text { occupational main group } \\
(\mathrm{n}=37)\end{array}$} & \multirow[t]{2}{*}{$\begin{array}{l}\text { sub-major group } \\
(n=28)\end{array}$} & \multirow[t]{2}{*}{$\begin{array}{l}\text { sub-major group } \\
(\mathrm{n}=43)\end{array}$} \\
\hline & $\begin{array}{l}\text { occupational } \\
\text { group }(n=86)\end{array}$ & $\begin{array}{l}\text { occupational } \\
\text { group }(n=88)\end{array}$ & & & \\
\hline 3 & $\begin{array}{l}\text { occupational order } \\
(n=334)\end{array}$ & $\begin{array}{l}\text { occupational } \\
\text { order }(n=369)\end{array}$ & $\begin{array}{l}\text { occupational group } \\
(n=144)\end{array}$ & $\begin{array}{l}\text { minor group } \\
(n=116)\end{array}$ & $\begin{array}{l}\text { minor group } \\
(n=120)\end{array}$ \\
\hline 4 & $\begin{array}{l}\text { occupational class } \\
\text { ( } n=1 \text { 991) }\end{array}$ & $\begin{array}{l}\text { occupational } \\
\text { class }(n=2287)\end{array}$ & $\begin{array}{l}\text { occupational sub-group } \\
(\mathrm{n}=700)\end{array}$ & \multirow[t]{2}{*}{$\begin{array}{l}\text { unit group } \\
(n=390)\end{array}$} & \multirow[t]{2}{*}{$\begin{array}{l}\text { unit group } \\
(n=436)\end{array}$} \\
\hline 5 & & & $\begin{array}{l}\text { occupational type } \\
(\mathrm{n}=1286)\end{array}$ & & \\
\hline \multirow[t]{4}{*}{$\begin{array}{l}\text { Official } \\
\text { institutions }\end{array}$} & $\begin{array}{l}\text { Statutory Health } \\
\text { Insurance }\end{array}$ & $\begin{array}{l}\text { Federal } \\
\text { Statistical Office }\end{array}$ & Statutory Health Insurance & $\begin{array}{l}\text { International } \\
\text { Labour Office }\end{array}$ & International Labour Office \\
\hline & $\begin{array}{l}\text { German Pension } \\
\text { Funds }\end{array}$ & & German Pension Funds & \multirow[t]{3}{*}{ European Union } & \multirow[t]{3}{*}{ European Union } \\
\hline & \multirow{2}{*}{$\begin{array}{l}\text { Federal Employ- } \\
\text { ment Agency }\end{array}$} & & Federal Employment Agency & & \\
\hline & & & Federal Statistical Office & & \\
\hline \multirow[t]{5}{*}{$\begin{array}{l}\text { Studies } \\
\text { (examples) }\end{array}$} & \multirow{5}{*}{$\begin{array}{l}\text { lidA - German } \\
\text { cohort study on } \\
\text { work, age and } \\
\text { health }\end{array}$} & $\begin{array}{l}\text { BIBB/BAuA } \\
\text { Employment } \\
\text { Survey }\end{array}$ & $\begin{array}{l}\text { BIBB/BAuA Employment } \\
\text { Survey }\end{array}$ & $\begin{array}{l}\text { BIBB/BAuA Employ- } \\
\text { ment Survey }\end{array}$ & BIBB/BAuA Employment Survey \\
\hline & & $\begin{array}{l}\text { Socio-econom- } \\
\text { ic Panel (SOEP) }\end{array}$ & $\begin{array}{l}\text { Socio-economic Panel } \\
\text { (SOEP) }\end{array}$ & $\begin{array}{l}\text { Socio-economic } \\
\text { Panel (SOEP) }\end{array}$ & Socio-economic Panel (SOEP) \\
\hline & & \multirow[t]{3}{*}{$\begin{array}{l}\text { German Health } \\
\text { Update (GEDA) }\end{array}$} & $\begin{array}{l}\text { German Health Update } \\
\text { (GEDA) }\end{array}$ & $\begin{array}{l}\text { German Health } \\
\text { Update (GEDA) }\end{array}$ & German Health Update (GEDA) \\
\hline & & & $\begin{array}{l}\text { lidA - German cohort study } \\
\text { on work, age and health }\end{array}$ & \multirow{2}{*}{$\begin{array}{l}\text { Transitions and Old } \\
\text { Age Potential } \\
\text { (TOP) }\end{array}$} & $\begin{array}{l}\text { European Working Conditions } \\
\text { Survey (EWCS) }\end{array}$ \\
\hline & & & $\begin{array}{l}\text { Gutenberg Health Study } \\
\text { (GHS) }\end{array}$ & & $\begin{array}{l}\text { Survey of Health, Ageing and } \\
\text { Retirement in Europe (SHARE) }\end{array}$ \\
\hline
\end{tabular}

use as a proxy for job exposures in rehabilitation patients. For this purpose, we give both an example for a sole routine data analysis and an example for a secondary data analysis based on survey data linked to routine data. We report the association between job exposure indices according to the occupation on the one hand and return-to-work prognosis after rehabilitation and patient reported outcome measures on the other hand.

\section{Methods}

The German Pension Insurance is by far the most relevant payer for medical and vocational rehabilitation for persons in working age in Germany [28]. Usually, the main aim of these rehabilitation measures is to secure or restore the ability to work. In 2017, 1011578 medical rehabilitations and 165980 vocational rehabilitations were completed [29]. Therefore, in this paper, we used data of rehabilitation measures financed by the German Pension Insurance. For this purpose, we analysed 2 different datasets:

First, we used a Scientific Use File (SUF) provided by the Research Data Centre of the German Pension Insurance (http://www.fdz-rv. de) (dataset 1). The longitudinal dataset called "SUFRSDLV15B" contains data from 3734861 persons in total. Of those, 1836448 persons completed at least one medical rehabilitation within an 8-year time period from 2008-2015. The data is a factually anonymised sample of $20 \%$ of all completed medical rehabilitations covered by the German Pension Insurance. Individual contribution and sociodemographic data are available for 3 more years (20052007). In addition, the Scientific Use File contains longitudinal data for vocational rehabilitation and persons with retirement entry (including due to disability) and data for several reference populations in the indicated time period. Because we investigate return-towork, we included only data for $n=1242174$ persons who were full-time or part-time employed and had completed medical rehabilitation, excluding rehabilitation aftercare or programmes like rehabilitation sports and functional training. We excluded unemployed persons and persons not working or staying at home before their rehabilitation as well.

Second, we used data from an own study conducted with 2530 rehabilitation patients insured with the German Federal Pension Insurance (dataset 2). The rehabilitants were asked by postal mail to fill in a questionnaire covering various bio-psycho-social impairments and resources shortly prior to the start of medical rehabilitation, e. g. depressive symptoms, general self-efficacy, and social support ( $\vee$ Table 3 ). This survey data was joined with routine data including the occupation according to KIdB 88 from the insurance account and with data from the discharge report. A detailed de- 
- Table 2 Occupations and corresponding job exposure indices: Example.

\begin{tabular}{|c|c|c|c|c|c|c|c|}
\hline \multicolumn{3}{|c|}{$\begin{array}{l}\text { Occupations in physical security, personal protection, fire protection and workplace safety } \\
\text { (KIdB 2010: 531) [20] }\end{array}$} & \multicolumn{5}{|c|}{ Job Exposure Indices [39] } \\
\hline Classification Title & Digit & Code & OJI & OPI & OSI & HWI & CAI \\
\hline Occupations in traffic, logistics, safety and security & 1 & 5 & n.a. & n.a. & n.a. & n.a. & n.a. \\
\hline Occupations in safety and health protection, security and surveillance & 2 & 53 & 5 & 4 & 9 & 4 & 6 \\
\hline $\begin{array}{l}\text { Occupations in physical security, personal protection, fire protection and } \\
\text { workplace safety }\end{array}$ & 3 & 531 & 7 & 6 & 9 & 4 & 7 \\
\hline $\begin{array}{l}\text { Occupations in physical security, protection of valuables, and personal } \\
\text { protection }\end{array}$ & 4 & 5311 & 7 & 5 & 10 & 3 & 6 \\
\hline unskilled/semiskilled tasks & 5 & 53111 & 7 & 6 & 10 & 4 & 8 \\
\hline skilled tasks & 5 & 53112 & 7 & 6 & 10 & 4 & 8 \\
\hline Occupations focusing on workplace safety and safety technology & 4 & 5312 & 4 & 4 & 5 & 2 & 6 \\
\hline skilled tasks & 5 & 53122 & n.a. & n. a. & n.a. & n. a. & n. a. \\
\hline complex tasks & 5 & 53123 & 6 & 6 & 6 & 4 & 7 \\
\hline highly complex tasks & 5 & 53124 & 6 & 6 & 6 & 4 & 7 \\
\hline Occupations in fire protection & 4 & 5313 & 9 & 7 & 10 & 6 & 10 \\
\hline skilled tasks & 5 & 53132 & 8 & 6 & 10 & 5 & 9 \\
\hline complex tasks & 5 & 53133 & 8 & 6 & 10 & 5 & 9 \\
\hline highly complex tasks & 5 & 53134 & 8 & 6 & 10 & 5 & 9 \\
\hline Pool attendants and lifeguards & 4 & 5314 & 7 & 7 & 9 & 4 & 8 \\
\hline skilled tasks & 5 & 53142 & 7 & 6 & 9 & 4 & 8 \\
\hline Private detectives & 4 & 5315 & 6 & 5 & 9 & 3 & 6 \\
\hline skilled tasks & 5 & 53152 & 7 & 6 & 9 & 4 & 7 \\
\hline Debt collectors & 4 & 5316 & 5 & 4 & 9 & 4 & 6 \\
\hline skilled tasks & 5 & 53162 & 7 & 6 & 9 & 4 & 7 \\
\hline $\begin{array}{l}\text { Occupations in physical security, personal protection, fire protection and } \\
\text { workplace safety (with specialisation, not elsewhere classified) }\end{array}$ & 4 & 5318 & n. a. & n.a. & n.a. & n.a. & n.a. \\
\hline skilled tasks & 5 & 53182 & n. a. & n.a. & n. a. & n.a. & n. a. \\
\hline complex tasks & 5 & 53183 & 7 & 6 & 9 & 5 & 7 \\
\hline highly complex tasks & 5 & 53184 & n. a. & n.a. & n.a. & n.a. & n.a. \\
\hline $\begin{array}{l}\text { Supervisors and managers in physical security, personal protection, fire } \\
\text { protection and workplace safety }\end{array}$ & 4 & 5319 & 9 & 10 & 9 & 6 & 8 \\
\hline $\begin{array}{l}\text { Supervisors in physical security, personal protection, fire protection and } \\
\text { workplace safety }\end{array}$ & 5 & 53193 & 7 & 6 & 9 & 5 & 8 \\
\hline $\begin{array}{l}\text { Managers in physical security, personal protection, fire protection and } \\
\text { workplace safety }\end{array}$ & 5 & 53194 & 7 & 6 & 9 & 5 & 8 \\
\hline
\end{tabular}

scription of the study design, inclusion and exclusion criteria, and the assessments and routine data used can be found elsewhere $[30,31]$. We included in our analyses all 2019 patients with a documented occupation and return-to-work prognosis at the end of rehabilitation as specified previously [32].

Ethical approval was obtained for the analyses of both datasets from the ethics committee of the Charité - Universitätsmedizin Berlin (EA1/204/15 and EA1/207/18). The survey was registered at ClinicalTrials.gov (NCT02304601, Universal Trial Number U11111215-9823) and the participants gave written informed consent. We carried out this work according to the Good Epidemiological Practice and the Good Practice of Secondary Data Analysis [33, 34]. The reporting follows the German Reporting Standard for Secondary Data Analyses (STROSA) [35].

\section{Job Exposure Index}

The Job Exposure Index was first introduced by Kroll in 2011 [9] based on the BIBB/BAuA Employment Survey 2006 using data from about 20000 persons in work aged 15 years or older in Germany [36]. In 2015, an update of the index was published using data of the BIBB/BAuA Employment Survey 2012 [37, 38]. 39 items assessing different kinds of job exposures were included into the Overall Job Exposure Index via job-exposure matrices by assigning the assessed job exposures to the coded occupations. Multi-level-analyses were applied to take advantage of the hierarchical structure of the job classifications ( $\triangleright$ Table 1 ) and to take into account the limited number of cases per single occupation. Furthermore, these analyses were adjusted for gender, age, working time in hours per week, and time in years working in the current occupation [9]. Be- 
- Table 3 Association of the Overall Job Exposure Index (OJI) and patient reported outcome measures.

\begin{tabular}{|c|c|c|c|c|}
\hline \multirow{2}{*}{$\begin{array}{l}\text { patient-reported outcome measures [31] } \\
\text { (scales, range, polarity) }\end{array}$} & \multicolumn{4}{|c|}{ mean (SD) stratified according to overall job exposures (OJI) } \\
\hline & low $(n=776)$ & moderate $(n=1025)$ & high $(n=218)$ & Cohens $\mathrm{d}^{*}$ \\
\hline specific work-related problems (SIMBO-K) ${ }^{* *}$ & $31,2 \%$ & $35,5 \%$ & $41,7 \%$ & 0,253 \\
\hline best work ability (WAS, $0-10,-)$ & $4,9(2,6)$ & $4,4(2,8)$ & $4,1(2,8)$ & 0,300 \\
\hline subjective prognosis of gainful employment (SPE, $0-3,+$ ) & $1,3(1,1)$ & $1,5(1,1)$ & $1,6(1,1)$ & 0,303 \\
\hline depressive symptoms (HADS-D, $0-21,+$ ) & $7,4(4,3)$ & $7,8(4,4)$ & $8,0(4,2)$ & 0,128 \\
\hline anxiety (HADS-A, 0-21,+) & $8,5(4,3)$ & $8,9(4,3)$ & $9,0(4,4)$ & 0,100 \\
\hline general self-efficacy (GSE, 10-40, -) & $28,2(5,8)$ & $27,8(6,1)$ & $28,2(6,0)$ & 0,000 \\
\hline social support (IRES, 0-10, -) & $6,7(2,7)$ & $6,7(2,7)$ & $6,6(2,8)$ & 0,067 \\
\hline health behaviour (IRES, $0-10,-$ ) & $6,4(1,9)$ & $6,3(1,9)$ & $6,8(1,7)$ & 0,216 \\
\hline ability to function in daily life (IRES, $0-10,-$ ) & $4,8(2,2)$ & $4,8(2,2)$ & $4,5(2,1)$ & 0,160 \\
\hline impairment due to pain (PDI, $0-70,+$ ) & $26,7(15,0)$ & $28,3(15,3)$ & $26,7(15,9)$ & 0,003 \\
\hline comorbidity (SCQ, $0-39,+$ ) & $6,7(4,1)$ & $6,9(4,1)$ & $7,5(4,7)$ & 0,190 \\
\hline \multicolumn{5}{|c|}{$\begin{array}{l}\text { +: higher value means higher impairment, -: higher value means lower impairment. SD: standard deviation, SIMBO-K: Screening Instrument for } \\
\text { Detecting the Need of Work-Related Medical Rehabilitation (short form), WAS: Work Ability Score, SPE: Subjective Prognosis of Gainful Employment } \\
\text { Scale, HADS: Hospital Anxiety and Questionnaire, GSE: General Self-Efficacy Scale, IRES: Indicators of Rehabilitation Status Questionnaire, PDI: Pain } \\
\text { Disability Index, SCQ: Self-administered Comorbidity Questionnaire; } n=2019 .{ }^{*} \text { Cohens d: low vs. high overall job exposures. }{ }^{* *} \text { SIMBO-K: } \\
\text { percentage of present specific work-related problems }\end{array}$} \\
\hline
\end{tabular}

cause of too low number of cases for some occupations in the Employment Survey, the Job Exposure Index is not available for every single occupational code on all levels of the job classifications. In ISCO-08 e. g., the Overall Job Exposure Index is available in $85.5 \%$ of the 4 -digit-codes, $90.8 \%$ of the 3 -digit-codes and $95.4 \%$ of the 2-digit codes [39].

The Overall Job Exposure Index (OJI) is composed of all 39 items. Additionally, sub-indices are available which cover specific facets of job exposures: the Overall Physical Exposure Index (OPI), the Overall Psychosocial Exposure Index (OSI), the Carcinogenic Agents Index (CAI), and the Hard Working Index (HWI). CAI and HWI are single-item scales, the other indices are multi-item scales. All 5 indices can have values between 1 and 10 indicating the extent of job exposures according to 10 deciles. Consequently and by definition, $10 \%$ of the population is working in an occupation with the lowest job exposures (value ' 1 ') and $10 \%$ have an occupation with the highest job exposures (value '10'). The Overall job Exposure Index and its sub-indices are available for the job classifications KldB 92, KIdB 2010, ISCO-88 and ISCO-08 [39]. An example for the values of the 5 job exposure indices is given for the occupational group 531 according to KIdB 2010 (occupations in physical security, personal protection, fire protection, and workplace safety) in > Table 2.

\section{Data analysis}

We applied the Job Exposure Index and the sub-indices to both datasets described above. First, since the occupation is coded partly according to KIdB 88 and the Job Exposure Index is not available for that classification, we transformed the KIdB 88 into the KIdB 92 on the level of the 3-digit occupational orders [40]. From the years $2011 / 2012$ on, the occupation is documented according to KIdB 2010 for an increasing share of the cases [20].

Afterwards, we matched the values of all job exposure indices to the occupations beginning from the most accurate level (5-digits level occupational codes for KIdB 2010 and 3-digits for KIdB 92
( $\triangleright$ Table 1). In case the job exposure indices were not available on that level, we moved on to the next higher level (one digit less). All job exposure indices were categorized into low ( $1^{\text {st }}$ and $2^{\text {nd }}$ decile), moderate ( $3^{\text {rd }}$ to $8^{\text {th }}$ decile) and high job exposures ( $9^{\text {th }}$ and $10^{\text {th }}$ decile) [39].

We calculated the prevalence of low, moderate and high overall job exposures for completed medical rehabilitation measures of employed persons. We used the occupation documented in the year prior to the rehabilitation.

The association of job exposures according to all 5 Job Exposure Indices with the return-to-work prognosis after medical rehabilitation was analysed taking into account three different items of the rehabilitation discharge report ( $\triangleright$ Fig. 2 ): First, the capacity to work in the last job. Second, the capacity to work in any other job on the general labour market. The responses of these 2 items were categorised in 'able to work less than $3 \mathrm{~h}$ per day' versus 'able to work at least $3 \mathrm{~h}$ per day'. Third, the recommendation of a subsequent vocational rehabilitation (present vs. not present) was analysed. All information given in the discharge report is based on the appraisal of the responsible physician at the end of rehabilitation [41]. We included all cases with a documented occupation according to KIdB 2010. To evaluate potential differences dependent on the consulted job classification, the association of job exposures to the returnto-work-prognosis is described comparing the Overall Job Exposure Index according to KIdB 92 and the Overall Job Exposure Index according to KIdB 2010 ( $\triangleright$ Fig. 3).

To determine the association between self-reported impairments and resources we report mean values and standard deviations of the included scales stratified to the level of overall job exposures ( $\triangleright$ Table 3) [31]. The effect size is described with Cohens $\mathrm{d}$ for low versus high job exposures. For this purpose, we analysed the survey data (dataset 2), for all other analyses the Scientific Use File (dataset 1). 


\section{Results}

Over all reported years, the mean percentage of occupations documented by either KIdB 88 or KIdB 2010 is $91 \%$. In 2015, only $4.1 \%$ of medical rehabilitation treatments for the studied population have no occupation documented in the Scientific Use File. \ Fig. 1 shows that in 2011/12, the documentation of occupations according to KIdB 2010 begins and reaches its highest percentage in 2015 with $66.3 \%$, leaving an additional $29.6 \%$ cases coded according to KIdB 88.

The transformation of job classification KIdB 88 into KldB 92 was possible for $89,5 \%$ cases ( $n=1148314$ ) of medical rehabilitations, for $1.5 \%(n=19709)$ the transformation was not possible and for $9.0 \%(n=114914)$ of the cases no occupation was documented. For cases with an occupational code available according to KldB 92 after transformation, the Job Exposure Index could be assigned to the 3 -digit occupational orders in $95.5 \%$ and to the 2 -digit occupational groups in the remaining $4.5 \%$ of cases. For KIdB 2010, in $99.0 \%$ of cases the job exposure scores could be assigned to the 5 -digit occupational types, and in the other $1,0 \%$ to one of the higher levels of occupations.

\section{Prevalence of job exposures}

Among all cases of medical rehabilitation with a documented occupation using the Overall Job Exposure Index $(n=1147387)$ as basis for the calculation of prevalences of job exposures, there are $14.3 \%$ cases with a low exposure level, $62.0 \%$ with a moderate exposure level and $23.7 \%$ with a high exposure level.

\section{Association with return-to-work}

- Fig. 2 shows the percentage of persons with a reduced working capacity in the last job and in any other job of under $3 \mathrm{~h}$ per day after rehabilitation treatment and the percentage of recommendations for subsequent vocational rehabilitation. Results are reported for all five job exposure indices using the job classification KIdB 2010. The analysis shows, that over all 5 indices, a higher job exposure level is associated with a higher percentage of persons having a working capacity of less than $3 \mathrm{~h}$ per day in the last job and a higher percentage of recommendations for vocational rehabilitation after finishing their rehabilitation treatment. When job exposures are high, the proportion of persons with a predicted working capacity of less than $3 \mathrm{~h}$ per day in the last job is increased by a factor of about 4 compared to low-level job exposures (23.5 vs. $6.1 \%)$. In contrast, the association to reduced working capacity in the general labour market hardly differed according to the level of job exposures (2.9 vs. $2.4 \%$ ). This pattern can be found in all five job exposure indices. The differences between low and high job exposures for the 3 outcomes were the least distinct for the Overall Psychosocial Exposure Index.

- Fig. 3 demonstrates the association between overall job exposures and three parameters of the return-to-work-prognosis comparing the Overall job Exposure Index based on the occupation according to the job classification KIdB 92 and KIdB 2010. In general, the differences between both classifications are rather small for all exposure categories and outcomes. The differences are most pronounced for the valuation of working capacity in the last job.

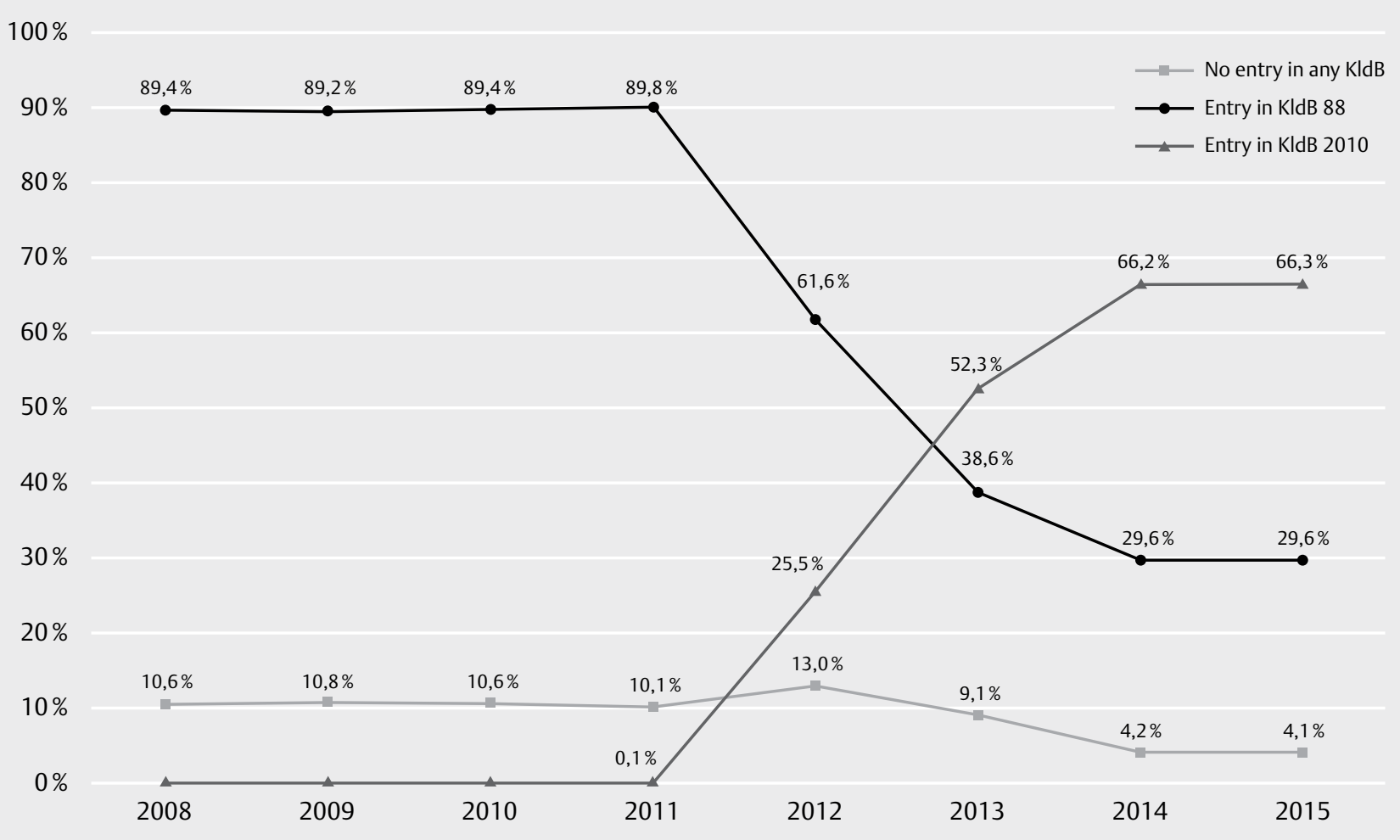

- Fig. 1 Available entries in job classifications from 2008 to 2015 (year of start of rehabilitation) for cases of medical rehabilitation treatment in working population (in \%) ( $n=1282$ 937). KldB: German Classification of Occupations. 


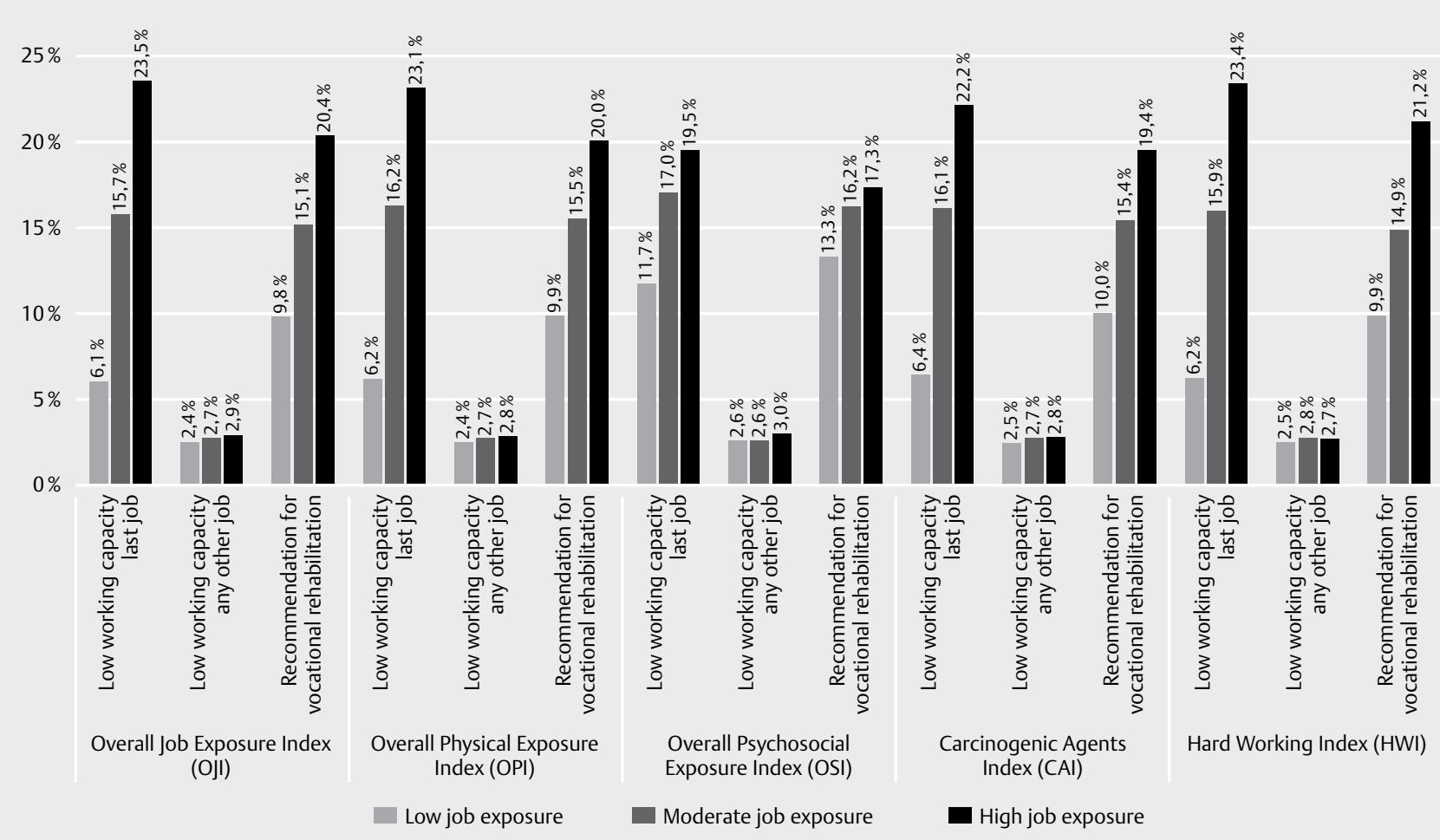

- Fig. 2 Association of Job Exposure Indices according to KldB 2010 and low working capacity in the last job ( $n=346250$ ), low working capacity in any other job ( $n=346167)$ and recommendation for vocational rehabilitation $(n=351597)$ (in \%). KldB: German Classification of Occupations.

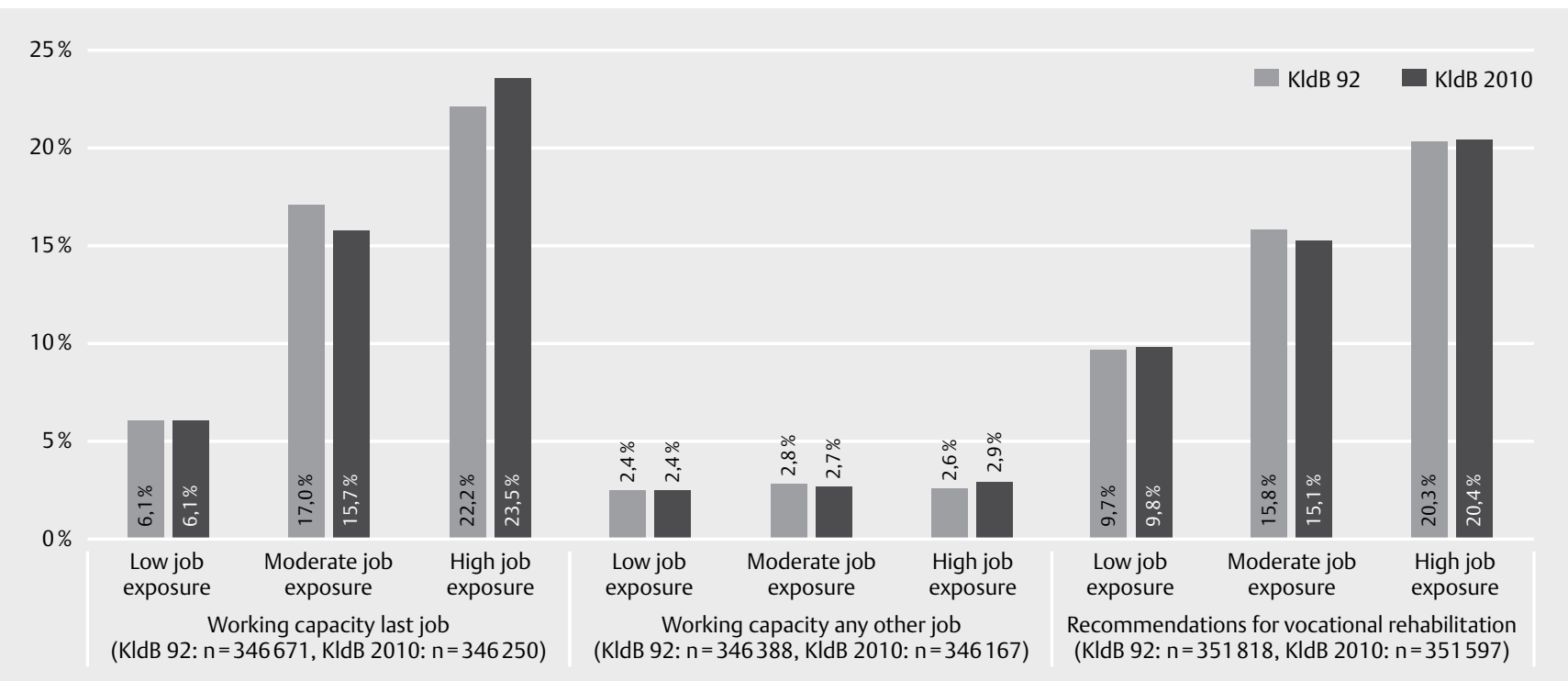

- Fig. 3 Association of the Overall Job Exposure Index and the return-to-work prognosis comparing the job classifications KIdB 92 and KldB 2010 (in \%). KldB: German Classification of Occupations.

\section{Association with self-reported impairments and resources}

The analysis of the survey data (dataset 2 ) shows that there is an association between job exposures and various patient reported outcome measures. Higher job exposures and job-related scales are associated with effect sizes of around 0.3 according to Cohens $d$. The association of other impairments and resources with job exposures were less pronounced or there was no association revealed ( $\triangleright$ Table 3). For the Overall Physical Exposure Index and the Hard Working Index the calculated effect sizes were slightly higher, for 
the Overall Psychosocial Exposure Index lower than for the Overall Job Exposure Index (data not shown).

\section{Discussion}

The Job Exposure Index and its sub-indices could be linked to the vast majority of medical rehabilitations of employed persons. The prevalence of high job exposures is estimated at $23.7 \%$. On the whole, this is comparable to the results of the BiBB/BAuA Employment Survey [9]. The percentage of a low work capacity after rehabilitation in the last job practised before rehabilitation roughly rises by the factor four when high job exposures are present in contrast to low job exposures. For the recommendation for a subsequent vocational rehabilitation, the percentage increased by a factor of about two when comparing employees with high and low job exposure. On the contrary, the capacity to work in any other job on the general labour market after rehabilitation hardly differed between the 2 groups of job exposures (high vs. low) ( $\mathbf{F i g}$. 2). This indicates that the Job Exposure Index is indeed capable to reflect exposures related to specific occupations. In line with the results of previous studies, the analyses of the sub-indices indicate that physical job exposures are related more specifically to occupations than psychosocial job exposures [9].

In addition to the routine data analyses, survey data reveals an association of job exposures with several self-reported impairments and resources ( $\triangleright$ Table 3 ). Estimated effect sizes are small or very small. The largest effect sizes were detected for the association with job-related scales. This finding is plausible and congruent with previous analyses using the first version of the Job Exposure Index [32]. In other studies using the Job Exposure Index, there was a significant association described with sick leave, depressive symptoms and the subjective general health status [9, 37].

The results of our analyses of job exposures determined by the 5-digit-level occupational types according to KIdB 2010 were similar to those taking into account the 3-digit-level occupational orders according to KldB 92 ( $\triangleright$ Fig. 3). At first sight, one would expect to have more pronounced results for the 5 -digit-level-analyses. It remains unclear if the findings point out a lower validity of the occupational codes at the most accurate level of the job classification or if the results are due to the small heterogeneity of job exposures on that level ( $\triangleright$ Table 2). It was shown that the variability of job exposures is largest at the higher levels of the job classifications [9]. In addition, the index is not available for all occupations on the most accurate level anyway. Summarizing the present findings, it may be sufficient to apply the Job Exposure Index to the 3-digit-level when analysing routine data of the social security funds.

\section{Limitations}

The Job Exposure Index is based on job-exposure matrices. Job-exposure matrices are well established to reflect job exposures for various research questions including the association of job exposures to subjective health, injuries, early retirement, lifestyle factors, and health behaviour $[4,12,14,15]$. It has been shown for single exposures and diseases that the use of job-exposure matrices can provide similar results as the individual assessment of work-related exposures [42-44].
However, job-exposure-matrices including the Job Exposure Index are not able to describe extensive risk assessments of single specific job exposures precisely. This is valid for psychosocial job exposures in particular. Instead, the Job Exposure Index by Kroll reflects the overall level of job exposures and sorts all occupations in a hierarchical order according to the extent of overall (physical and psychosocial) job exposures. This allows - in contrast to other jobexposure-indices or to job classifications - an easy application of the Job Exposure Index in secondary data analyses for all occupations according to KIdB or ISCO. Only one degree of freedom is needed for the adjustment of job exposures in multivariate analyses. Other existing job-exposure-matrices are restricted to certain occupations or to specific facets of job exposures [9].

In addition, the Job Exposure Index takes into account the high intra-class-correlation of job exposures within different levels of job classifications by applying multilevel analyses. Furthermore, the Job Exposure Index is adjusted for factors that are associated with job exposures (age, gender, working hours per week, and time in years working in the current occupation). Other job-exposure-matrices did not take these aspects into consideration [16]. Meanwhile, the Job Exposure Index developed by Kroll has been applied to various national and international datasets [9, 32, 37, 45-47].

The validity of the occupational code in routine data of the social security funds has been questioned $[48,49]$. Our findings - an existent association of job exposures and the work capacity in the last job on the one hand, but a virtually non-existent or low association to the work capacity in any other job on the other hand indicate that the documented occupational code reflects the real occupation at least to a substantial degree. This correspondents to the appraisal of the occupational code by Grobe and Ihle [21]. To enhance the quality of the documentation of occupations, the Federal Employment Agency offers an online-tool and a free telephone hotline for companies to determine the correct occupational code according to KldB 2010 (http://bns-ts.arbeitsagentur.de). However, the occupations according to KIdB 88 have to be considered less valid, as there was no verification or controlling mechanism implemented.

Besides, there were more missing values for the occupation before the introduction of the KIdB 2010 (about 10 to $11 \%$ from 2008 to 2011 and about $4 \%$ from 2014 to 2015, - Fig. 1). A selection bias due to missing values cannot be ruled out. Especially persons working in lower-skilled occupations may be underrepresented. Furthermore, data from the German Pension Insurance include information concerning rehabilitation measures financed by the German Pension Insurance only. Hence, self-employed persons and public officials e. $g$. are underrepresented or not represented at all.

\section{Application of the Job Exposure Index}

There are numerous possibilities to apply the Job Exposure Index to routine and survey data. The necessary condition is the coding of the occupation according to KIdB 92, KIdB 2010, ISCO-88, ISCO08 or a classification that can be transformed into one of these job classifications (e.g. KldB 88) ( $\triangleright$ Table 1). The Research Data Centre of the German Pension Insurance offers different cross-sectional and longitudinal Scientific Use Files for the scientific community upon request (http://www.fdz-rv.de). These datasets combine data from all 16 agencies of the German Pension Insurance and include 
the occupational code according to KIdB 88 and KIdB 2010, respectively. The Scientific Use Files are widely used in rehabilitation research [50-56].

It should be mentioned that the Scientific Use Files provided are a powerful resource that needs some experience and careful considerations in order to get useful results. Data is stored for persons and events, respectively in the different datasets provided. For most analyses it is necessary to merge person-related information (age, sex, e. g.) with events (medical rehabilitation, vocational rehabilitation, times of disability pension, e. g.) which is not always selfexplanatory for this kind of longitudinal dataset. Also, a good bit of knowledge is necessary to understand the explanation of the content of variables from the codebook provided, which is only available in German. Sometimes it has proven useful to contact the Research Data Centre for further clarification.

In addition to the German Pension Insurance, the German Federal Employment Agency is an important funder of vocational rehabilitation in Germany [57]. Various Scientific Use Files are provided by the Research Data Centre of the German Federal Employment Agency at the Institute for Employment Research (IAB). The Sample of Integrated Labour Market Biographies (SIAB) allows to track the occupation over time [58]. Another Scientific Use File is called Panel Study Labour Market and Social Security (PASS-ADIAB) and links survey data to administrative data of the IAB [59].

The occupation according to KIdB is available in the data of the statutory health insurances in principle as well [48]. In contrast to the German Pension Insurance, there are currently no Scientific Use Files available of any of the health insurance funds. In addition, the occupational code is not part of the combined health care dataset at the German Institute of Medical Documentation and Information (DIMDI). The Institute for Applied Health Research (InGef) provides the only known database which contains the occupational code and covers data from different statutory health insurances. In general, the accessibility to data of health insurance funds is limited so far. However, for specific epidemiological studies, it was possible to combine data from different statutory health insurances or to match data from the German Pension Insurance with health insurance data including the occupational code [24,60-62]. The Federal Statistical Office annually conducts the microcensus, a dataset which includes the coded occupation. Every 4 years, health-related outcomes are part of the survey [63].

In addition to pure routine data analyses, it is possible to either link data from epidemiological studies to routine data containing the occupational code or to assess and code the occupation in studies themselves. The German Socio-Economic Panel Study (SOEP), the German Cohort Study on Work, Age and Health (lidA), the Gutenberg Heart Study and surveys from the Robert Koch-Institute are examples for the latter approach $[25,26,64]$. The linkage of routine and survey data is more and more frequent in rehabilitation research [32,65-68]. On an international level, Scientific Use Files of the European Working Conditions Survey (EWCS) and the Survey of Health, Ageing and Retirement in Europe (SHARE) are available $[22,45,69]$. In addition, SHARE was linked with administrative data from the German Pension Insurance (SHARE-RV) [70]. These datasets enable analyses of the association of job exposures and health-related outcomes, too.

\section{Conclusion}

Routine data of the German Pension Insurance and other social security providers includes the information of the occupation for the vast majority of insured persons in working age. Applying the Job Exposure Index, this information may be used to represent job exposures. The Job Exposure Index enables researchers to take into account occupation-specific job exposures in routine data analyses or in survey data linked to routine data that contains the occupation according to the German or international job classification without any additional data collection effort. This opens up new possibilities in rehabilitation research and beyond.

It has to be emphasised, however, that the Job Exposure Index is not capable of replacing the individual assessment of job exposures. Furthermore, psychosocial job exposures are less precisely represented by the Job Exposure Index than physical job exposures. The validity of the index on the different levels of job classifications and the utility of the Job Exposure Index and its sub-indices should be further researched.

\section{Funding}

Both studies were funded by the German Federal Pension Insurance. The funder had no role in study design, data analysis, interpretation of data, preparation of the manuscript or in the decision to publish the results.

\section{Conflict of Interest}

The authors declare that they have no conflict of interest.

\section{Literature}

[1] Dragano N, Schneider L. Work related psychosocial factors and the risk of early disability pensioning: a contribution to assessing the need for rehabilitation. Rehabilitation 2011; 50: 28-36

[2] Liebers F, Brendler C, Latza U. Age- and occupation-related differences in sick leave due to frequent musculoskeletal disorders. Bundesgesundheitsblatt 2013; 56: 367-380

[3] Peter R, March S, du Prel J-B. Are status inconsistency, work stress and work-family conflict associated with depressive symptoms? Testing prospective evidence in the lidA study. Soc Sci Med 2016; 151: 100-109

[4] Rommel A, Varnaccia G, Lahmann N et al. Occupational injuries in Germany: population-wide national survey data emphasize the importance of work-related factors. PLoS One 2016; 11: e0148798

[5] Backé EM, Seidler A, Latza U et al. The role of psychosocial stress at work for the development of cardiovascular diseases: a systematic review. Int Arch Occup Environ Health 2012; 85: 67-79

[6] Roski C, Romppel M, Grande G. Risk factors for disability pensioning caused by mental disorders - A systematic review. Gesundheitswesen 2017; 79: 472-483

[7] Rose U, Müller G, Freude G et al. Working conditions and mental health among salaried physicians: A nationwide comparison with a representative sample of employees. Gesundheitswesen 2019; 81: $382-390$ 
[8] Dragano N, Wahrendorf M, Müller K et al. Work and health inequalities: the unequal distribution of exposures at work in Germany and Europe. Bundesgesundheitsblatt 2016; 59: 217-227

[9] Kroll LE. Konstruktion und Validierung eines allgemeinen Index für die Arbeitsbelastung in beruflichen Tätigkeiten anhand von ISCO-88 und KIdB-92. Methoden - Daten - Analysen 2011; 5: 63-90

[10] Niedhammer I, Bourgkard E, Chau N. Occupational and behavioural factors in the explanation of social inequalities in premature and total mortality: a 12.5-year follow-up in the Lorhandicap study. Eur ] Epidemiol 2011; 26: 1-12

[11] Nübling M, Stößel U, Hasselhorn H-M et al. Measuring psychological stress and strain at work: evaluation of the COPSOQ Questionnaire in Germany. GMS Psycho-Social Medicine 2006; 3: 1-14

[12] Boedeker W, Friedel H, Friedrichs $M$ et al. The impact of work on morbidity-related early retirement. J Public Health 2008; 16: 97-105

[13] Goldberg M, Kromhout H, Guénel $P$ et al. Job exposure matrices in industry. Int J Epidemiol 1993; 22: S10-S15

[14] Meyer S-C, Nelen A. Do occupational demands explain the educational gradient in health? Bonn: Institute for the Study of Labor; 2014

[15] Bondo Petersen S, Flachs EM, Prescott EIB et al. Job-exposure matrices addressing lifestyle to be applied in register-based occupational health studies. Occup Environ Med 2018; 75: 890-897

[16] Nübling M, Vomstein M, Haug A et al. Are reference data from the COPSOQ database suitable for a JEM on psychosocial factors at work? Zbl Arbeitsmed 2017; 67: 151-154

[17] Taeger D. Basic principles of a job exposure matrix. Zbl Arbeitsmed 2017; 67: 143-150

[18] Rijs KJ, van der Pas S, Geuskens GA et al. Development and validation of a physical and psychosocial job-exposure matrix in older and retired workers. Ann Occup Hyg 2014; 58: 152-170

[19] Stegmann M. Meldeverfahren zur Sozialeversicherung. Änderung der Erfassung der Angaben über Bildung, Beruf und Beschäftigungsform im Meldeverfahren der Sozialversicherung. Deutsche Rentenversicherung 2009; 9: 487-500

[20] Paulus W, Matthes B. The German Classification of Occupations 2010 - Structure, Coding and Conversion Table. Nuremberg: Institute for Employment Research; 2013

[21] Grobe T, Ihle P, Stammdaten und Versichertenhistorien. In: Swart E, Ihle P et al., (Hrsg.). Routinedaten im Gesundheitswesen: Handbuch Sekundärdatenanalyse: Grundlagen, Methoden und Perspektiven. Bern: Huber; 2014: 28-37

[22] Eurofound. Sixth European Working Conditions Survey - Overview Report (2017 update). Luxembourg: Publications Office of the European Union; 2017

[23] International Labour Office. International Standard Classification of Occupations. Geneva: ILO; 2012

[24] Hasselhorn HM, Peter R, Rauch A et al. Cohort profile: the lidA Cohort Study. A German Cohort Study on Work, Age, Health and Work Participation. Int J Epidemiol 2014; 43: 1736-1749

[25] Prigge M, Köhr M, Pfeiffer N et al. Coding of occupational information in the baseline examination of the Gutenberg Health Study using the German Classification of Occupations KIdB 2010 - presentation of the procedure and the data quality. Zbl Arbeitsmed 2014; 68: 153-161

[26] Wagner GG, Frick JR, Schupp J. The German Socio-Economic Panel study (SOEP) - evolution, scope and enhancements. Schmollers Jahrbuch 2007; 127: 139-169

[27] Lange C, Jentsch F, Allen J et al. Data resource profile: German Health Update (GEDA). The health interview survey for adults in Germany. Int J Epidemiol 2015; 44: 442-450

[28] Nowossadeck E, Pohlner S, Kamtsiuris P. Utilization of medical rehabilitation services in Germany: a comparative analysis of survey and routine data. Gesundheitswesen 2017; 79: 1058-1064
[29] German Federal Pension Insurance. Rehabilitationsleistungen im Zeitablauf 2018. Berlin: 2018

[30] Brünger M, Spyra K. Prevalence of comorbid depressive symptoms in rehabilitation. Results from a cross-indication, nation-wide observational study. J Rehabil Med 2016; 48: 903-908

[31] Brünger M, Streibelt M, Schmidt C et al. Psychometric testing of a generic assessment tool for the identification of biopsychosocial impairments in persons with an approval for medical rehabilitation. Rehabilitation 2016; 55: 175-181

[32] Brünger M, Spyra K. Importance of job demands for rehabilitation patients - application of an index according to occupations. Rehabilitation 2018; 57: 239-247

[33] Swart E, Gothe H, Geyer S et al. Good Practice of Secondary Data Analysis (GPS): guidelines and recommendations. Gesundheitswesen 2015; 77: 120-126

[34] Hoffmann W, Latza U, Baumeister SE et al. Guidelines and recommendations for ensuring Good Epidemiological Practice (GEP): a guideline developed by the German Society for Epidemiology. Eur J Epidemiol 2019; 34: 301-317

[35] Swart E, Bitzer EM, Gothe H et al. A Consensus German Reporting Standard for Secondary Data Analyses, Version 2. Gesundheitswesen 2016; 78: e145-e160

[36] Rohrbach-Schmidt D. The BIBB/IAB- and BIBB/BAuA-Surveys of the working population on qualification and working conditions. Data and methodological reports. Bonn: Federal Institute for Vocational Education and Training (BIBB); 2009

[37] Kroll LE. Aktualisierung und erneute Validierung eines Index für Arbeitsbelastungen auf Basis von KldB-2010, KIdB-92, ISCO-08 und ISCO-88. Gesundheitswesen 2015; 77: A363

[38] Rohrbach-Schmidt D, Hall A. BIBB/BAuA Employment Survey. Data and methodological reports. Bonn: Federal Institute for Vocational Education and Training (BIBB); 2013

[39] Kroll LE. Job Exposure Matrices (JEM) for ISCO and KIdB (Version 2.0). Updated for ISCO-08 and KIdB-2010 and including an additional Heavy Work Index. datorium 2015, doi:10.7802/1102

[40] Stegmann M. Vergleichbarkeit der Berufklassifikationen öffentlicher Datenproduzenten und die Transformation in prominente sozialwissenschaftliche Klassifikationen und Skalen. DRV-Schriften 2005; Bd 55: 114-153

[41] German Federal Pension Insurance. Der ärztliche Reha-Entlassungbericht. Leitfaden zum einheitlichen Entlassungsbericht in der medizinischen Rehabilitation der gesetzlichen Rentenversicherung 2015. Berlin: 2015

[42] Dale AM, Ekenga CC, Buckner-Petty S et al. Incident CTS in a large pooled cohort study: associations obtained by a Job Exposure Matrix versus associations obtained from observed exposures. Occup Environm Med 2018; 75: 501-506

[43] Madsen IEH, Gupta N, Budtz-Jorgensen E et al. Physical work demands and psychosocial working conditions as predictors of musculoskeletal pain: a cohort study comparing self-reported and job exposure matrix measurements. Occup Environ Med 2018; 75: 752-758

[44] Hanvold TN, Sterud T, Kristensen P et al. Mechanical and psychosocial work exposures: the construction and evaluation of a gender-specific job exposure matrix (JEM). Scand J Work Environ Health 2019; 45: 239-247

[45] Kroll LE, Müters S, Höbel ] et al. European Validation of ISCO-based Job Exposure Matrices using EWCS 2010. Eur J Public Health 2015; doi: ckv175003

[46] Hassoun L, Herrmann-Lingen C, Hapke U et al. Association between chronic stress and blood pressure: findings from the German Health Interview and Examination Survey for Adults 2008-2011. Psychosom Med 2015; 77: 575-582 
[47] Santi I, Kroll LE, Dietz A et al. Occupation and educational inequalities in laryngeal cancer: the use of a job index. BMC Public Health 2013; 13: 1080

[48] Damm K, Lange A, Zeidler J et al. Implementation of the new German job role code and its application in claims data analysis. Possibilities and limitations. Bundesgesundheitsblatt 2012; 55: 238-244

[49] March S, Iskenius M, Hardt J et al. Methodological considerations for data linkage of primary and secondary data in occupational epidemiology studies. Bundesgesundheitsblatt 2013; 56: 571-578

[50] Hetzel C, Streibelt M. The return to work status one year after vocational retraining: is it an indicator for long term occupational participation? Rehabilitation 2018; 57: 175-183

[51] Falk J, Haaf H-G, Brünger M. Rehabilitation of patients with peripheral arterial disease in the context of guideline recommendations. Rehabilitation 2019; 58: 225-233

[52] Fechtner S, Bethge M. Outpatient vs. inpatient rehabilitation: findings of a propensity score matched analysis. Rehabilitation 2017; 56 : 372-378

[53] Holstiege J, Kaluscha R, Jankowiak $S$ et al. Associations of the employment status during the first 2 years following medical rehabilitation and long term occupational trajectories: implications for outcome measurement. Rehabilitation 2017; 56: 31-37

[54] Christiansen M, Schmidt JP, Shkel D et al. A projection of the need for rehabilitation in Germany till 2040 based on demographic factors. Gesundheitswesen 2018; 80: 489-494

[55] Barth A, Aretz B, Doblhammer G. Risk of reduced earning capacity pension due to cardiovascular diseases after medical rehabilitation: An event history analysis based on German Statutory Pension Insurance data. Gesundheitswesen 2019, doi:10.1055/a-0832-2117

[56] Köckerling E, Sauzet O, Hesse B et al. Return to work after temporary disability pension. Gesundheitswesen 2019, doi:10.1055/a-0883-5276

[57] Nivorozhkin A, Reims N, Zollmann P et al. Vocational rehabilitation comparing clients of the Federal Employment Agency and the German Pension Insurance. Rehabilitation 2018; 57: 149-156

[58] Antoni M, Ganzer A, vom Berge P. Sample of integrated labour market biographies (SIAB) 1975-2014. Nuremberg: Research Data Centre of the German Federal Employment Agency at the Institute for Employment Research; 2016

[59] Trappmann M, Beste J, Bethmann A et al. The PASS panel survey after six waves. J Labour Market Res 2013; 46: 275-281
[60] Dannenmaier ], Ritter S, Jankowiak S et al. Utilization of rehabilitation after disk surgery - A cross-sectoral analysis of claims data from Statutory Health Insurance and German Federal Pension Fund. Rehabilitation 2017; 56: 313-320

[61] Ritter S, Dannenmaier J, Jankowiak $S$ et al. Total hip and knee arthroplasty - utilization of postoperative rehabilitation. Rehabilitation 2018; 57: 248-255

[62] March S, Antoni M, Kieschke J et al. Quo vadis data linkage in Germany? An initial inventory. Gesundheitswesen 2018; 80: e20-e31

[63] Kuntz B, Kroll LE, Hoebel J et al. Time trends of occupational differences in smoking behaviour of employed men and women in Germany: results of the 1999-2013 microcensus. Bundesgesundheitsblatt 2018; 61: 1388-1398

[64] Swart E, Stallmann C, Schimmelpfennig M et al. Gutachten zum Einsatz von Sekundärdaten für die Forschung zu Arbeit und Gesundheit. Berlin: German Federal Institute for Occupational Safety and Health (BAuA); 2018

[65] Bethge M, Spanier K, Peters E et al. Self-reported work ability predicts rehabilitation measures, disability pensions, other welfare benefits, and work participation: longitudinal findings from a sample of German employees. J Occup Rehabil 2018; 28: 495-503

[66] Kessemeier F, Stockler C, Petermann F et al. The significance of work motivation for rehabilitation success. Rehabilitation 2018; 57 : 256-264

[67] Nübling R, Kaluscha R, Krischak G et al. Outcome quality in medical rehabilitation: relationship between "Patient-Reported Outcomes" (PROs) and social security contributions. Rehabilitation 2017; 56: 22-30

[68] Streibelt M, Brünger M. How many work-related therapeutic services do patients with severe restrictions of work ability receive? Analysis of a representative rehabilitation sample across indications. Rehabilitation 2014; 53: 369-375

[69] Börsch-Supan A, Brandt M, Hunkler C et al. Data resource profile: the Survey of Health, Ageing and Retirement in Europe (SHARE). Int J Epidemiol 2013; 42: 992-1001

[70] Mika T, Czaplicki C. SHARE-RV: Eine Datengrundlage für Analysen zu Alterssicherung, Gesundheit und Familie auf der Basis des Survey of Health, Ageing and Retirement in Europe und der Daten der Deutschen Rentenversicherung. RVaktuell 2010; 12: 396-400 